Sugar and Garments 



\section{Fiji: Sugar and sweatshirts, migrants and remittances}

\section{Kate Hannan}

There is general agreement that the Fiji economy is moving towards a particularly difficult period. It is recognised that the negative effects on Fiji's sugar and garment industries flowing from the promotion of free trade in our globalised world are resulting in an ever-more challenging economic and social environment that requires careful, fair, innovative and, above all, prompt and effective planning responses. WTO pressure on the EU to end agricultural subsidies and the end of the Multi-Fibre Arrangement (MFA) without its replacement by alternative measures that would serve to apportion quotas for clothing, footwear and textile markets in the USA have rebounded on the Fijian economy. Those who have been commenting on the worrying prognosis for Fiji's economy range from Savenaca Narube, the Governor of Fiji's Reserve Bank, to local media and an array of grassroots religious groups. They also include a wide range of academics, Australian and New Zealand politicians and representatives from aid organisations, including the ADB and Oxfam. All agree that Fiji's sugar industry faces economic hurdles that are set so high they might well end the industry's role as an important source of grassroots income and as a leading provider of the country's foreign exchange income. They also all recognise that the decline in employment opportunity and exchange earning capacity of Fiji's garment industry is likely to be permanent. ${ }^{l}$

In this chapter I will briefly profile the problems facing Fiji's sugar and garment industries before suggesting two possible scenarios for the future. In the first scenario, I concentrate on the employment and housing implications flowing from the likely flood of rural-to-urban migrants in the wake of the restructure of the sugar industry. I begin by noting the obvious point that the loans and general economic assistance being made available for the amelioration of the serious economic effects of changed EU quotas and price preferences must be carefully spent. I then argue that even in the case of agreed and well-designed restructuring initiatives that are promptly implemented (and to date there is little sign of this), it is unlikely that these monies will be distributed in a sufficiently egalitarian manner to offset the significant disruption that will come with the measures needed to make Fiji's sugar industry competitive in today's global marketplace. ${ }^{2}$ What is likely to happen is that a significant number of sugar farmers and people employed in the industry will find that they have no option but to migrate to the cities, particularly the capital, Suva. They will be following the path taken by previous sugar farmers who felt they had little in 
the way of alternative options when their land leases were not renewed and, like these farmers, they will hope to find work in the informal economy where it is estimated that more than 60 per cent of Suva's residents are already employed. ${ }^{3}$

In my second scenario, I canvass the possibility of the foreign exchange now earned by the export of sugar and garments being replaced by funds remitted by Fijian workers employed overseas. This scenario is already unfolding. There is a large increase in remittances to Fiji from workers who have accessed overseas employment and this must be a cause of some optimism, particularly if remittance funds can be channelled successfully into areas that reach beyond consumption and the reproduction of a further generation of unskilled workers. Areas such as the funding of rural cooperatives or grassroots banks offering micro-financing show considerable promise. There are, however, also causes for concern in relation to remittances and I discuss a number of these, including a current worldwide push by international financial interests to regulate, formalise and profit from the funds workers send home to their families and communities. ${ }^{4}$

\section{Sugar and garments}

The difficult position that Fiji's sugar industry faces now that the EU will no longer pay a heavily subsidised price for a substantial proportion of the country's crop is underlined by a number of issues that are coming to the fore on a regular basis. Among these is the Fiji Government's action in taking out a loan from the ADB for no less than $\$ F 41$ million (approximately $\$ A 33.7$ million). This loan is for the stated purpose of 'helping to develop alternative livelihoods for rural dwellers at risk in the restructure of the sugar industry'. The loan will cover half the estimated cost of the alternative livelihoods project - almost \$A67.4 million - and must be repaid over 25 years with an upfront five-year grace period. It seems that the future must now be mortgaged to pay for past neglect of an industry that has hidden behind, and been nourished by, first British and then EU trade preferences. The Fiji Government is also scheduled to directly provide \$US8.7 million and the Fiji Development Bank \$A11.7 million to the project to 'help develop alternative livelihoods' and this is in addition to a significant tranche of EU 'conscience money' and Fiji's usual and significant aid receipts from a number of sources, including Australia's \$A30.5 million aid package for the year 2005-06 and a further \$A33.8 million for 2006-07. ${ }^{5}$

In June 2000 when the Lomé Conventions were reconstituted as the Cotonou Agreement, the European Commission (EC) was already signalling its intention to alter, or at least to update, trade arrangements between itself and the African, Caribbean and Pacific (ACP) states. The EC used the Cotonou Agreement to clearly flag that changes in trade relations were to take place 'in conformity with 
WTO rules' and to point out that updated trading arrangements would come into force no later than January 1, 2008. ${ }^{6}$

In spite of many commentators noting the obvious point that 'the relationship between the EU and the ACP has never been an equal one', the Cotonou Agreement has been presented as one that 'foresees the negotiation between September 2002 and December 2007 of economic partnership agreements (EPAs)'. These agreements are to cover the delicate terrain of being WTO-compatible and based on an apparently benevolent initiative that boosts asymmetrical reciprocity, which 'allows ACP regions to open their markets to the EU at a slower rate than the EU would open its market to the $\mathrm{ACP}^{\prime} .{ }^{7}$ However, while this benevolence will obviously be appreciated, the EC is left in a position where it must take at least some responsibility for the harsh economic and social effects that will attend the forthcoming changes it has adopted in relation to the preferred status that has long been enjoyed by ACP banana and sugar producers selling into the EU market. The commission flagged that in the case of sugar, 'the real price offered to ACP Sugar Protocol producers will be substantially reduced under the EU's current proposals for CAP [Common Agricultural Policy] reform to begin in $2006^{\prime}$, and it is in this context that commentators have noted:

i. that 'the EU's commitments under the Cotonou Agreement to ensure the continued viability of the Protocol industries will be difficult, if not impossible, to maintain in higher-cost countries following [this] reform'; ${ }^{8}$ and

ii. that 'Article I of the EU-ACP Sugar Protocol provides that "the European Community undertakes for an indefinite period to purchase and import, at guaranteed prices, specific quantities of cane sugar, raw or white, which originate in the ACP States and which these States undertake to deliver"'. 9

The latter point was interpreted as meaning that in strictly legal terms the EU was obliged to negotiate and agree to a guaranteed price for specific quantities of sugar with ACP Sugar Protocol countries such as Fiji. However, the unequal nature of the relationship between the EU and the ACP states has meant that the EC alone has decided what it will do. At one level, the EC has taken the view that the transitional assistance that is to be negotiated under the EPAs will atone for its withdrawal from 'a binding undertaking which was of indefinite duration' and at another level the EC is pressing the argument that the Common Organisation of the Market in Sugar (COMS), to which the Sugar Protocol is linked and on which it depends, 'can be amended'. Changes to the COMS can be made with matters such as WTO commitments in mind. Faced with this situation, ACP countries have been left with only a narrow range of realistic alternative options. ${ }^{10}$ 
One of the options open to the governments of ACP countries severely affected by the EC's change of approach is to draw public attention to what they see as the EC's breach of the principle of fairness. For example, Fiji's Minister for Foreign Affairs and External Trade, Kaliopate Tavola, complained to the EC that its intended removal of trade quotas and price subsidies did not take Fiji's situation (and the situation of the other affected ACP countries) 'into account in any way'. He added that the ending of quotas and price subsidies for Fijian sugar, which the EC had flagged, was 'completely at odds with EU development policy, the general objectives of the Doha Development Round of the WTO, and the pursuit of the UN Millennium Development Goals'.

Ministers and administrators representing other ACP countries have also noted what they depict as a 'cold-hearted' approach being taken by the EU and they too have questioned the legality of the EU's alteration of the Sugar Protocol. They have been keen to point out that 'the ACP has faithfully met its obligations and should reasonably expect the EU to respect its commitments enshrined in the Protocol in terms of the three guarantees of price, access and indefinite duration'. For their part, EC sources have noted that 'some ACP countries have used the economic rents associated with preferences to secure long-term efficiency gains by diversifying into new export sectors ... [while] for other countries ... preferences have resulted in resource allocations to uncompetitive sectors.' These are sectors that are uncompetitive in world market terms. The EC then argues that the removal of market access preferences and price subsidies will result in gains in the long-term. However, it is admitted that in the shorter term, 'any large-scale reallocation of production could undermine employment and foreign exchange earnings which would impose high adjustment costs'. In spite of significant funds being made available from a range of sources, including and particularly the EU, Fiji, and those who have been associated with the Fijian sugar industry, will have to pay 'high adjustment costs'. ${ }^{11}$

While the EC's assessment of the negative employment and foreign exchange effects of the end of their preferential arrangements on recipient ACP countries smacks of blaming the victim, it is the case that Fijian interests sat back and sheltered under the preferential umbrella and chose to take little or no account of the possibility of their future exposure to the full force of the global marketplace. This is a view that I expect underpinned a remark made by Australia's Foreign Minister, Alexander Downer, who argued that 'European Union practices have done Fiji's sugar industry enormous damage over the years. $^{\prime 12}$

Those who have profiled Fiji's sugar industry note that 'in and before the 1980s, Fiji was regarded internationally as an efficient producer and reliable supplier of high quality sugar'. This is no longer the case. Sugar was 'the single largest industry in the country during the 1970's' and, although its success in terms of 
the relative size of its economic contribution to national coffers has been reduced (particularly and most recently in the period since 1994), the industry still dominates the rural economy. A number of scholars estimate that it continues 'to provide employment directly or indirectly to about 51,000 people'. This would mean that more than ' 250,000 people, or $31 \%$ of the country's population, are directly reliant on the sugar industry'. There are said to be about 22,000 individuals (the Government's estimate is 21,000 ) who are sugar growers and a further 20,000 who are engaged as cane harvesters. They farm an average of only three to four hectares and raise less than 200 tonnes of cane per annum. The productivity of these small leased holdings has been falling for some time and the average net income of sugar farming households is recognised to already be below the poverty line. 13

It is a generally agreed view that low productivity in Fiji's sugar industry as a whole 'stem[s] from the inability of the FSC [the Fiji Sugar Corporation, currently with a 67 per cent government-owned shareholding] over many years, to improve its efficiency and provide leadership to the industry'. The continuing need to contend with inefficient milling procedures, a decrepit sugar rail system, and tensions over the renewal of land leases are among the issues that have further exacerbated problems associated with the relatively small size of leaseholdings, low returns to farmers and the low level of investment. There is also an array of problems associated with Fiji Governments and authorities, which have consistently adopted a delayed, dithering and dispute-ridden approach to restructuring the industry. What has happened is that the end of EU preferences has left the industry with nowhere to go other than to effect a massive restructuring program. About 90 per cent of Fiji's raw sugar is exported to international markets, with the majority of this being taken up by the EU under terms established and agreed to under the ACP/EU Sugar Protocol. In March 2005 it was estimated that the EU was paying 529 euros per metric tonne for Fijian sugar. This amount is now scheduled to be reduced to approximately 329 euros per metric tonne in the next five years, a reduction of more than one-third. The price paid by the EU under the Sugar Protocol 'has been frozen since 1993/4 at more than three times the world price'. ${ }^{14}$ The substantial (even catastrophic) price reduction for raw sugar exported to the EU that is looming must surely be recognised as the 'straw that will break the back' of an already ailing and beleaguered industry. 15

At this point in my argument I think it is well worth adding a comment made by Isikeli Mataitoga, CEO of Fiji's Ministry of Foreign Affairs and External Trade. He recognised that, at least in the short term, Fiji can expect to 'still export its Sugar Protocol quota allocation of 163,600 tonnes but with decreasing price (initially a reduction of 25 per cent) to come into effect from 2006/2007 and a further 11 percent from 2007/2008'. This means that under present conditions and production costs, 'Fiji would simply be unable to supply the EU market on 
a commercial basis'. This is a view that is supported by Fiji's Sugar Cane Growers Council, whose leader, Jaganath Sami, has stated that the new European prices would mean that under the present conditions for sugar production and milling, 'by 2009, at least 65 per cent of cane farmers may not be viable'. He went on to note that 'the revenue of the farmers would be reduced by as much as 31 per cent under the new prices' and we can add that this is in the context where, as noted above, the average net income of sugar farmers is already considered to be below the poverty line. 16

In spite of the advantageous price paid by the EU for a large proportion of Fiji's sugar exports (and in part as a consequence of the declining productivity of the sugar industry), between 1997 and 2001 Fiji's garment manufacture replaced sugar as the country's leading export earner. ${ }^{17}$ Garment industry exports, however, will not be capable of replacing sugar exports now or in the future. Fiji-based garment manufacture is in decline. Like the sugar industry, the garment industry is occupying an increasingly untenable position in relation to the international marketplace. This situation is made clear when:

i. it is remembered that the garment industry is largely labour-intensive and that investment capital involved in the clothing, textile and footwear sector of the global economy has for the most part sought out the cheapest reliably available labour in the international marketplace; and

ii. it is pointed out that the average income for a Chinese clothing, footwear and textile worker engaged in the cut, make and trim production that has sustained the Fijian garment industry is 700-800 yuan a month or approximately \$A114-130 a month. ${ }^{18}$ The pay for a Fijian garment industry worker has hovered about $\$ F 80$ a week (though quite often less, down to \$F60) with 'illegal' overtime now being unusual. The Fijian wage would equal approximately \$A225-280 a month. ${ }^{19}$

Descriptions of day-to-day working conditions in Fiji, including the attitude of managers towards workers, show that they are hardly better than in Chinese factories and the wages paid are considered to be below the poverty line in terms of the cost of living in urban centres. It is widely recognised that 'despite Fiji's relatively high labour costs, wages of garment factory workers are low compared to other industries'. However, they are much higher than the wages paid in China and Chinese workers (in China and those who have come to Fiji to work) are considered to be more highly skilled and more productive. They work longer hours and there is far less absenteeism among Chinese workers. ${ }^{20}$

Until January 1, 2005, Fiji could produce behind the shield of the MFA that had been operating in concert with various preference and protection arrangements provided by Australian manufacturers. The MFA that was in place in the global marketplace for three decades had run its course and in the absence of any 
further international agreement effectively offering preferential treatment for various geographically located sectors of the garment industry, a number of developing countries, including Fiji, found that their industries could not compete with the cheap labour offered by Chinese rural-to-urban migrant workers. While Fijian production has already found several niche markets (and this approach clearly offers a way forward for a number of manufacturers with an attendant reprieve for their workers), benefits derived from bilateral trading arrangements between Australia and Fiji cannot be expected to offset the advantages offered to manufacturers by the Chinese-based clothing, textile and footwear sector.

The South Pacific Regional Trade and Economic Cooperation Agreement (SPARTECA), in tandem with a number of other arrangements including those bearing the titles Import Credit Scheme (ICS), Tax-Free Factory Scheme (TFF) and SPARTECA-Textile, Clothing and Footwear scheme (S-TCF), has allowed Fiji's exports to enter Australia (and to a lesser extent New Zealand) duty-free. The finished garments exported under these arrangements have had to meet 50 per cent rules-of-origin requirements (later, in 2001, reduced to a minimum of 35 per cent). These arrangements allowed Fiji's garment industry to boom during the 1990s. ${ }^{21}$ However, faced with the coup of May 2000, coupled with the end of the ICS in June the same year (a scheme that had 'given incentives for Australian companies to source raw materials from Asia, add value in Australia and then export to Fiji for offshore processing where the finished product could re-enter Australia under SPARTECA' ${ }^{22}$ ), and now battling the consequences of the end of the MFA, Fiji-based manufacturers are finding that their industry has been dealt first one blow and then another. Moreover, rules of origin advantages - even if now reconstructed in a streamlined, clear and well-organised fashion into a program that successfully succeeded the ICS could obviously do nothing to reinstate the loss of Fiji's MFA-protected quota for garments to be sold into the US market. It is now too late for specially constructed Australian preferences to produce the outcome needed to ensure the continued health of Fiji's cut, make and trim garment industry. Nevertheless, Fiji's Foreign Minister found himself again pleading for a better export deal for his country. In spite of the already agreed extension of S-TCF advantages for a further seven years (until 2011), in September 2005 he requested that Australia further 'relax its current rules relating to market access to Australia for garments manufactured in Fiji'. This reduction in origin requirements would be from 35 per cent to 25 per cent. ${ }^{23}$

It is also worth noting that there is now concern among Fiji's garment manufacturers that if Australia signs a bilateral free trade agreement with China, they would be further disadvantaged. Fiji-based manufacturers are stating that if this happens the jobs of their remaining garment workers 'are likely to disappear overnight'. It is clear that their fear over this issue is doing its part in 
further eroding their confidence in their increasingly fluid and already fragile industry. ${ }^{24}$

The obvious and widely agreed view that Fiji's garment industry has made a significant contribution to the nation's economy must now be tempered by the observation that, in the protected form that it took, the industry was likely to fail to increase its productivity levels to a point where it would justify its relatively high wages and on-costs. It is now clear that the industry will no longer play its previous role in absorbing low-skilled workers and providing foreign exchange earnings. The best-case scenario is that, with government support and clear goals, the industry will be in a position to nurture a smaller, but internationally competitive garment industry that will survive without the benefit of preferences or subsidies. ${ }^{25}$

In a manner that mirrors criticism of the sugar industry's failure to restructure while protected by EU price and quota preferences, it has been pointed out that the Fiji-based garment industry 'illustrates the problems preferences can cause developing economies'. The industry and its workers became trapped in labour-intensive, 'low-skill and low-technology' cut, make and trim manufacture. Nevertheless, it will be sorely missed. The consequences of its demise will be 'immeasurable' and will have a particularly sad and serious impact 'on the tens of thousands of urban poor ... who are inextricably linked to its continued existence'. Most estimates are that the industry continues to employ some 12,000 to 15,000 workers, mostly women and often Indo-Fijian women, whose incomes are estimated to affect as many as 80,000 people. ${ }^{26}$

When considering the low-wage, low-technology state of Fiji-based garment manufacture (a situation nurtured by MFA access to garment markets in the USA, and both nurtured and exacerbated by 'tied trade' arrangements with Australia), most commentators would agree with the observation that preferences 'represent bad trade and bad development policy approaches'. ${ }^{27}$

\section{Scenario one: Migrants, settlements and the informal economy}

In this first scenario I will outline what could happen if Fiji governments continue to be indecisive in the face of the significant economic problems that are on the horizon. They are also the problems that will come into view if the Government is unwilling and unable to ensure that the money offered for the purposes of restructuring the sugar industry and providing alternative avenues of employment for sugar farmers who are disadvantaged by the restructure fails to 'trickle-down'. With the sugar industry in decline and faced with, at best, a choice between significant restructure, the inclusion of new forms of production such as ethanol production, or closure, and a garment industry that is already 
well in decline, the Fiji Government and the people of Fiji obviously cannot afford anything other than prompt, decisive, effective and efficient action. ${ }^{28}$

In spite of the loan that has been approved by the ADB, a report published by the bank notes that 'accessible alternative occupations' for those who leave sugar leases that are no longer viable and who have been displaced by shrinking employment opportunities in sugar-related occupations are likely to be difficult to obtain. It is already clear that 'formal employment will not keep pace with population drift to urban areas'. This will mean that the rural-to-urban drift will accelerate the expansion of informal settlement in Suva and there will be an increased reliance on informal avenues for employment. ${ }^{29}$ Already, anecdotal evidence suggests that the profile of the residents of the Suva-Nausori corridor has changed. It has been commonly agreed that residents in this corridor were once predominantly indigenous Fijians. Today, it is said that almost half are Indo-Fijians. The deleterious effect on the sugar industry of the end of a significant number of sugar-farm leases and the reduced productivity of the continuing leases, coupled with an attendant reduction in confidence in the industry, is a sensible and reasonable way to account for this change.

The problems associated with urbanisation in Pacific Island countries are already well documented. They are depicted as 'numerous and serious'. Lack of sufficient employment opportunities (particularly in the more secure and predictable formal sector) in peri-urban areas of spontaneous urban settlement and the downward pressure on wages in the formal and informal sectors created by competition for work, are already cause for concern among planners and academic commentators. They also note the obvious pressure on already hard-pressed services such as a reliable water supply (now often having to be accommodated in Suva's outer suburban areas by the use of a 44-gallon drum covered by a flap of plastic and left on the roadside to be filled from a water truck) and waste disposal (with a significant portion finding its way into waterways and lagoons). Indeed, the overall profile of urban poverty in Fiji is becoming a matter of acute concern. ADB policy-makers have estimated that for the period 2002-03 urban poverty in Fiji rose to the point where it included some 30 to 40 per cent of urban residents. ${ }^{30}$ (Just a little more than five years earlier, in 1997, a Government/UNDP report found that in Fiji as a whole 25 per cent of people were living below the poverty line, with a further 25 per cent surviving just above this line). It has also been recognised that as many as 83 per cent of those in poverty are employed. They are the working poor, and research has shown that many of these working poor are already living in informal urban settlements. ${ }^{31}$

Urban commentators have been keen to point out that in the context of today's global economy, there are cities that gain and cities that lose. The cities that gain are obviously those favoured by substantial international investment. Some 
cities have become 'mega' or 'world' cities. They include New York, London and Shanghai and maybe even Sydney. They are cities that face outward, embracing the world marketplace. However, other cities have suffered as the manufacturing base they grew on has been shipped offshore. These cities include Detroit and Pittsburgh, Sheffield and Liverpool, Dresden and Leipzig. (In Australia they are rust-belt cities such as Geelong, Newcastle and Wollongong.) In order to again flourish, these cities have had to reinvent themselves. Dresden has wanted to become a new centre for micro-electronics in Germany, the English city of Liverpool has presented itself as a cultural centre and the Australian cities of Geelong, Newcastle and Wollongong have been keen to foster their image as university cities. ${ }^{32}$ However, there are obviously other types of cities. They are not losing or in danger of losing their residents and they have not been left behind and forced to retool and reorient because the manufacturing base that gave rise to their very existence has moved offshore. These are developingcountry cities that are growing due to rural push. And, in the case of Fiji, the likely outcome of a future considerable contraction in sugar production means that cities (particularly Suva) are likely to undergo substantial growth. ${ }^{33}$

The changing spatial form of cities is reflecting the dynamics of globalisation and it is clear that Fiji's cities have been and will continue to be affected by this dynamic. It is equally clear that it will be difficult for Suva to take advantage of advice that suggests that cities 'lower down the [global] system' will 'have to find niches in the global marketplace in order to survive'. This advice is not appropriate. ${ }^{34}$ Finding a market outlet (or niche) is obviously a good idea, but the city will survive and grow even without this market chance. Though Fiji's second city of Lautoka can be twinned with the tourist entry town of Nadi to share the benefits that derive from tourism and so take advantage of a global market niche, Suva is not geographically well placed to take advantage of tourism. Suva is likely to survive as the country's administrative centre and grow as a warehouse for those whose incomes have benefited from protective sugar and garment markets and pricing arrangements, and who are now to be left without a regular, formal income. 35

While a number of First-World urban commentators either ignore the type of developing-country city I have outlined above (doing no more than express concern over cities where the population rises, but employment opportunities are barely increasing or static), others are busily identifying interesting possibilities for cities such as Suva. This latter group of commentators argues that we should stop deploring the growth of informal settlements, squatter towns and even slums. They argue that we should value measures such as 'spontaneous housing'. They are keen to point out that there are benefits to be derived from 'self-help' housing and the growth in the informal economy that comes with significant levels of rural-to-urban drift. Indeed, this approach seems to be 
already having an effect. In their latest pronouncement on development in the Pacific region, those who set Australia's aid goals have been arguing that self-help and self-employment must be encouraged. They have noted the benefit that would be gained from 'removing regulatory barriers in the informal sector' and have even noted that measures such as moving street-traders on because 'local authorities decide to "clean up the town"' (and quite often it is because they lack formal permission and business licences) are not sensible initiatives in the context of very high and still rising rates of urban unemployment. ${ }^{36}$

In the West, the process of increased industrialisation and urban growth usually accommodated the growing number of urban residents' need for formal employment. The cities needed the workers, but this is an experience that is in stark contrast with that of most developing countries where there is insufficient formal employment to satisfy residents' needs. ${ }^{37}$ Commentators who are arguing for reassessment of Third World informal self-help communities and their employment patterns recognise that the informal economy, where those who come to town might well find work, has its faults. These have been extensively debated. They know that 'the great mass of unskilled workers has encouraged the growth of "informal sectors" in every developing country' (reflecting a lack of investment in human capital) and they are well aware that these workers are subject to insecure employment and are not protected by minimum wage provisions. They also lack access to welfare services, and health and safety provisions in the workplace are often ignored. Nevertheless, there is no doubt that many poor urban households derive their living from the informal sector. They and their families depend on it. It is also clear that this sector represents concrete action by the poor to provide employment and to service their own and others' needs. 38

Today a number of respected sources such as the ILO have not only recognised the importance and value of this sector, they have argued that it would derive considerable benefit from 'state intervention in the areas of credit, technical support and infrastructure'. In concert with this advice, a number of Fiji-based academics have noted that most participants in their country's informal sector depend on moneylenders and relatives to access finance. They estimate that these two sources account for 80 per cent of the finance used for investment in informal enterprises and that the interest charged by moneylenders is 'quite high'. They estimate that it averages 34 per cent per annum. Moreover, the Fiji Government has already recognised the need to support small, often family-run and often informal-sector enterprises and now has legislation in place to promote small and micro-enterprises. As well, aid donors are well aware of the benefits to be gained from offering micro-financing to these enterprises (for example, the EU has already established an EU/ACP Microfinance Framework Program). It therefore seems that the considerable body of grant and aid funds from a range of other sources that are to be used for the declared purpose of helping to 
'develop alternative livelihoods for rural dwellers at risk in the restructure of the sugar industry' should be extended to those who are or who will come to live in Suva. It will be sensible, indeed necessary, to extend the stated intention of 'livelihood' projects aimed at encouraging sugar farmers 'to engage in off-farm livelihoods by promoting the development of small and micro-enterprises' to urban areas and particularly to what will be a fast-growing informal sector. ${ }^{39}$

A further option with regard to addressing the needs of recently arrived rural-to-urban migrants begins with the observation that while developing-country governments have constructed public housing in answer to the demands of the poor, it is clear that their capacity to meet this housing demand is often woefully inadequate. In many cases even maintaining any existing stock of public housing is neglected, which might even worsen the plight of the poor. It is then no wonder that in a manner that parallels their advice in relation to the benefits that would derive from supporting the informal economy, some commentators have concluded that public housing has proved to be too costly for many developing-country governments and that this means that self-help shelter is the best realistically available option. They also note that spontaneous self-help shelters have an advantage over public housing because they are likely to be improved and upgraded over time. And, in most cases, self-built communities give rise to the spontaneous development of local religious-centred communities (churches, temples and mosques) and informal shops. These matters are clearly evident when viewing Suva's dilapidated supply of public housing and its squatter settlements. The obvious conclusion is that government attention would be better directed towards providing support for settlement housing. It has been pointed out that developing-country governments could (and should) establish formal land lease arrangements that provide some security for self-help settlements (indeed, the Fiji Government has done this in the past) and that this innovation should be given preference ahead of continuing investment in what has often become substandard and inadequate public housing. Many indigenous Fijian settlements in and around Fiji's main cities are based on informal arrangements with formally recognised indigenous landowning groups. However, with increasing numbers of Indo-Fijian families likely to come to town as rural-to-urban migrants, these arrangements will be forgone. These migrants do not usually have connections that would encourage formal indigenous-Fijian landowners to informally sublease land to them. This leaves them relying on the use of public land, and experience to date demonstrates that settlement then might often take place on land situated alongside suburban waterways or under high-voltage electricity cables. More appropriate areas set aside to be formally leased to self-help families would obviously be a very useful government innovation in this context. 
Those commentators who are urging that informal settlement should be reassessed also have a further point to make. It amounts to a sober caution. They note that we (scholars, policy-makers and journalists resident in developed and developing countries) have too often viewed self-help housing through a middleclass/permanent urban resident lens. We have therefore seen squatter settlements only as a source of increased social problems, as eyesores, a nursery for crime and violence, and an environmental hazard. These settlements are seen as a blot on the urban landscape rather than attempts by the poor to cater for themselves. However, even with the best intentions, one of the problems that it will be difficult to fund is the need for essential services, such as clean water, electricity and sewerage for self-help settlements. ${ }^{40}$ The latter situation is underlined in the case of Suva when it is remembered that there are squatter settlements that have been in existence for decades and that have had stable and continuous informal agreements with legally recognised landowners for this period of time and yet have not so far been able to raise the funds required to have electricity connected. The matter that all parties agree on is that ignoring the problems associated with informal urbanisation is most certainly ill-advised. ${ }^{41}$

\section{Scenario two: Workers and remittances}

Worker-remitted funds are already a well-established and recognised part of Fiji's economic landscape. However, today the quantity of remitted funds is substantially increased. This is a phenomenon that does not apply only to Fiji, or even only to the Pacific or the wider Asia-Pacific region. It is a worldwide occurrence and now respected and sober international institutions such as the ILO, the World Bank, the ADB, the Asia-Pacific Economic Cooperation (APEC) group and the IMF, together with a range of aid providers including the Australian Government and the EC, are paying attention to a situation that they now argue 'provides the most direct, immediate, and far-reaching benefit to overseas workers, their families, and their countries of origin'.

Overseas worker remittances to families and communities in Fiji have risen and risen again. By 2002 remittances from Fijian nationals living overseas had risen to an estimated \$F232.4 million (approximately \$A180 million). A year later, this figure was deemed to be \$F243.4 million (approximately \$A190 million) and, by the end of 2004, some sources estimated it was as high as \$F317 million (approximately \$A244 million). ${ }^{42}$ It is clear that remittances are replacing sugar and garments to rest alongside Fiji's flourishing tourist trade as the country's main means of generating foreign exchange. It is then equally obvious that 'maximising the benefits from international migration is crucial'. Other Pacific Island countries have already had considerable success in this area. Residents have enjoyed increased consumption and the provision of services including education and health facilities. They have also had access to improved housing and there are reports of some small-scale investment, though it is also generally 
agreed that consistently successful formal schemes (rather than local ad hoc schemes) aimed at encouraging investment instead of consumption have yet to be implemented.

It is against the background of increased living standards for residents of other Pacific Island countries and a demonstrated willingness for unskilled or semi-skilled Fijians to seek overseas employment that Fiji's Prime Minister, Laisenia Qarase, has applied pressure on richer neighbouring countries, particularly Australia, to accept Fijian 'guest workers'. He argued that if the Australian Government was to demonstrate real concern over good governance and security in the region, it must offer policy initiatives based on the premise that 'you can only have good governance and security if the citizens of the country are living a reasonable standard of living.' He went on to say that 'once you take that away, then you have very fertile grounds for instability'. Nevertheless, Australia's Foreign Minister, Alexander Downer, and Treasurer, Peter Costello, insisted that guest workers were not consistent with Australia's culture. Their immediate reaction was to conclude that Australian labour shortages would be better met by extending the visas of working travellers (usually young backpackers). ${ }^{43}$

The extent of the improvement in a family's lifestyle on the basis of remittances received has proved to be hard to estimate, but it should not be underestimated. While it is a widely held view that remittance funds are used primarily to meet the consumption needs of recipient families, we also already know from anecdotal evidence that remittances have been used as a source of low-level, informal-sector investment and we would expect this to have the advantage of not being encumbered with the very high interest rates imposed by moneylenders. John Connell, who has done a great deal of work on the issue of remittances by Pacific Island workers, has (together with Richard Brown) also noted that a range of developing countries have already adopted formal measures aimed at encouraging migrants to become investors. Connell and Brown have cited Turkish measures giving migrants preferences in village development cooperatives, a scheme in Pakistan that allows migrants to import machinery at concessional rates and to invest in export-processing zones; and a Bangladeshi Government offer of incentives for investing remitted funds domestically. ${ }^{44}$ These types of initiatives are becoming increasingly popular with developing-country governments and international policy advisors. There are many examples. It is currently being suggested to the Mexican Government that the role of micro-banks should be boosted in order to promote rural and peri-urban development using remittance monies. The argument used is a familiar one. It is that to date some $80-90$ per cent of remittance monies are dedicated to consumption and the reproduction of workers. While there is evidence that remittance funds are also used for housing and community projects and for health care and educational opportunities, and it might well be the case that they reach further than merely 
reproducing usually unskilled migrant workers, the argument that remitted funds are used predominantly for day-to-day consumption is well suited to the push for a more productive domestic approach to the use of remittances. Those promoting Mexican micro-banks have further boosted their argument by recognising that many families in the home country lack efficient and safe ways to save as well as lacking credit opportunities. They also cite the case of a micro-bank having been spontaneously established by home country members of a transnational community. This Mexican community was not only locked out of usual financial services by the lack of formal financial credentials held by citizens, but by geography. It was two hours from the nearest city on an unpaved road. The community offered as an example consists of a municipality that has 16,000 inhabitants in 60 small towns where somewhere between 40 and 70 per cent of the population have emigrated seeking work. The populations of the towns are reliant on remittances as their main source of income. ${ }^{45}$

At the same time as discussions, conferences and debates in the international arena have been focusing on the issue of worker remittances, commentators within and outside Fiji continue to display a somewhat ambiguous approach to the considerable growth in the country's remittances. On one hand, they note that skilled migrants such as nurses and teachers (together with rugby players and soldiers) represent a loss of scarce human capital and, on the other hand, they note that 'remittances are one of the main sources of domestic spending and are driving growth in the economy'. However, these commentators pay too little attention to what is most likely to be a fast-growing number of unskilled migrant workers who will remit funds to families who might well have been reliant mainly on the informal sector for their income. Unless they add this group to their consideration of the overseas worker/remittance issue, they will be out of step with what is happening on the ground in terms of the current international market in labour-time. Having made this point, I should also note that the pressure to provide opportunities for not only skilled, but unskilled potential migrants has been reflected in Prime Minister Qarase's plea to Australia to accept unskilled guest workers from Fiji; in the reported 'success' of the Pacific Forum in an agreement sought with the EC to allow guest workers to enter the EU; and in Fiji Government concern that 'some order and accountability' be brought to bear on 'the overseas job rush'. It is known that 'a sizeable number work, some illegally, in Australia, New Zealand, and the United States'. 46

It is quite clear that in spite of a degree of indecisiveness in terms of the approach of a number of commentators, 'Fiji is catching up fast on the world's latest lucrative exporting commodity: human labour'. However, a number of the pitfalls of this form of 'export' are already evident. Apart from those who are working overseas illegally, a number of Fijian workers remitting funds are newly employed in contract work in Kuwait or Iraq and this has led to some problems. In contrast with the 1,000 positions offered to Fijian men by the British Army, 
American contractors have been recruiting workers at rates much lower than the cost of their home-country workers and this has allowed some people to suggest that the present contracting of relatively cheap Fijian workers amounts to 'a form of 21 st-century black-birding'. 47

Among the problems associated with the present growth in overseas workers' remittances is one that has the smell of corruption. The promise of overseas employment is offered in order to make quick and less-than-honest money. There are a number of reports of fees as high as $\$ F 250$ to $\$ F 300$ being paid to be considered for an overseas posting, usually in Kuwait or Iraq, while $\$ F 150$ is a quite usual payment. There are reported to be as many as 20,000 paid-up applications for what is estimated to be a contract to supply a maximum of 2,000 workers. In the context of Fijian incomes, the application fee is considerable and is often borrowed. The Fiji Government initiated an investigation into the company concerned. ${ }^{48}$ A further problem associated with the now much greater reliance Fiji's citizens have on overseas remittances for employment opportunity, domestic consumption and the generation of foreign exchange earnings is the vulnerability to global forces that this form of income represents. Fiji's sugar and garment industries have already demonstrated just how hazardous the international marketplace is. A possible and equally serious vulnerability would be an economic contraction affecting host countries. This would, as we saw in the 1997 Asian financial crisis, lead to migrant workers (legal and illegal) being summarily repatriated. Their temporary status would ensure that they were ineligible for severance payments; quite often migrant workers have not received the wages owing to them. In the period after the Asian financial crisis it was reported widely that some employers took advantage of the vulnerability of their workers. They intentionally delayed or avoided wage payments and dismissed employees unfairly. In some places, most notably in Malaysia and Indonesia, xenophobia was expressed and had a marked effect on the treatment of migrant workers. In times of economic contraction, it is likely that workers will be given little or no notice of the change in their circumstances. Migrant workers, and indeed resident garment workers in Fiji, have often been presented with no more than a chained gate and, at best, a rough sign. ${ }^{49}$ And, as though the above concerns are not enough to consider, they by no means exhaust the problems countries and workers and their families might have to address in the course of depending on remittance incomes. For example, another global hazard that has appeared on the remittance agenda concerns the push by a number of well-established global financial institutions, and at least one regional grouping, APEC, to 'shape and formalise' (or more correctly, influence, regulate and, for private companies, derive further profit from) worker remittance payments.

In mid-2004, a symposium was held in Tokyo to discuss 'Shaping the Remittances Market by Shifting to Formal Systems'. APEC, the World Bank and the ADB sponsored this symposium. Their declared mission was to bring together 'key 
stakeholders to discuss opportunities and innovations in the cross-border remittance industry'. Their stated goal was to 'create market incentives for customers [workers remitting funds overseas] to shift from informal to formal financial systems'. The World Council of Credit Unions, a range of developing-country credit union providers, the Global Trade Association, Western Union (claiming its success and 'very strong business model') and those who favour 'ATM-based money transfers', and particularly 'Visa and MasterCard branded transfers', were uniformly keen to point to the problems associated with informal money transfer. They noted that when funds travelled home via friends and relatives the delivery time was often slow. They also noted the potential for loss and theft using informal transportation methods. They noted the potential for black-market transactions and money laundering and then cited the need to develop technologies, and delivery channels (with some suggesting not only ATMs, but pre-paid cards and use of the Internet) in order 'to harness' workers' remittances. In some cases, those presenting their 'research' to the symposium found it necessary to display a disclaimer stating that their company 'does and seeks to do business with companies covered in its research report [and] as a result, investors should be aware that the firm may have a conflict of interest that could affect the objectivity of the report'. The big business aspect of many of the presenters was displayed particularly clearly when Western Union boasted that it already had an 'unmatched global network' that included 5,600 locations in Citibank branches, 4,300 in Wal-Mart stores, 11,400 Fedex outlets, and no fewer than 30,000 outlets situated in McDonald's restaurants. Representatives from this same company also took time to lament that the market for global remittances was fragmented and immature. It offered scope for further development. 50

The attitude of international financial institutions to shaping and 'enhancing the efficiency of overseas workers' remittances' is in considerable contrast with others who have focused principally on a range of social issues related to these remittances.

Included among the institutions commenting on and attempting to influence the ever-increasing flow of worker remittances is the IMF. Its focus, however, differs from the concerns expressed by big business and those outlined by academics, social commentators and NGOs, who are advising that funds be spent in a manner that provides long-term benefits for the recipient society. IMF administrators are concerned that 'the compensatory nature of remittances presents a moral hazard, or dependency syndrome' and that this might impede economic growth. They argue that developing country residents' participation in productive endeavours might be reduced and it is on the basis of this concern that they are urging developing-country governments 'to come up with policies that will induce migrants to invest productively'. 51 
Yet another group of researchers who have been drawn into the forum shaping and regulating international remittances (including a number employed by the ADB) argue that developing-country governments whose workers are employed overseas should upgrade the quality of preparatory education, provide special skills training, identify new overseas labour markets and negotiate with host governments for the proper accreditation of their workers. These researchers have also noted that sending workers overseas who then remit funds to their families and communities at home might go some way to 'compensate for the losses that a sending country might incur from brain drain or the skimming of its highly skilled workers'. 52 This is the view that is currently reflected in Australian government plans and pronouncements in relation to remittances and overseas workers from the Pacific region. Claiming an important new direction for the aid program', Australian Prime Minister, John Howard, has announced the establishment of a Australia-Pacific Technical College. Noting that 'currently, workplace competencies in the Pacific often fall short of [Australian] industry requirements', Howard said that 'the college concept is aimed at increasing the number of skilled Pacific Island graduates as well as the quality of their training'. A detailed design of the college was scheduled to be presented to the Pacific Islands Forum meeting held in October 2006. 53

The Australian Government's skills-based approach to hosting overseas workers might well be comforting for Pacific Island governments when they consider the longer-term benefits of exporting their citizen workers. This is because it comes with the assurance that at least a portion of the human capital generated through this form of post-secondary education will be available for domestic purposes together with recognition of the obvious point that the wages (and therefore the expected remittances) of skilled workers are higher than those of unskilled and semi-skilled workers. However, it will not provide immediate employment and income for the workers who are already knocking at Australia's door. On the other hand, unless the workers of a sending country have access to skills acquisition (either by the relatively widespread provision of appropriate education through investment by aid providers or through the willingness and ability of domestic governments to harness income remittance monies for the purpose of educating workers), the present disadvantage in the international division of labour will be cemented ever more firmly into place.

\section{Conclusion}

The EC's decision to begin the withdrawal of its trade and pricing preferences for ACP sugar exports as early as 2006 has led to criticism even from within EU member states. For example, a British House of Commons report on fair trade and the EU's trade agreements with ACP countries, while not critical of the EC's reform of the sugar regime per se, gives voice to concern that due attention be paid to the implications of reform on ACP countries that rely on the EU market. 
The authors of the Report were seeking reassurance that capacity outside the sugar sector would be built in affected countries. ${ }^{54}$ If this production capacity is to be successfully built in Fiji then the funds borrowed by the Fiji Government from the $\mathrm{ADB}$, together with the considerable flow of monies from a range of other sources, including from the EC, will have to be used wisely. These funds must not be used only to restructure the ailing sugar industry. They will need to be invested in projects that provide employment opportunities for grassroots sugar producers who lose confidence in their industry and find they have little option other than to seek work in Fiji's growing informal sector.

Employment opportunities and income for citizens and their families and communities and the nation's capacity to generate foreign exchange are areas where the loss of EU sugar trading and pricing preferences will be keenly felt, particularly when it is remembered that the problems associated with the sugar industry do not stand alone. Fiji's garment industry has declined. The free market-informed decision to end the MFA without provision for any form of global market regulation aimed at offsetting the disadvantage to be borne by garment-producing countries that cannot match the low wages paid to China's rural-to-urban migrant workers is the most immediate cause of the difficulties now faced by Fiji-based garment manufacturers. These are difficulties that have combined with but cannot be overcome by trading concessions granted to Fijian manufacturers by the Australian Government. Extending the S-TCF scheme and reductions in 'rules-of-origin' percentages for cut, make and trim garments returning to Australia will not compensate for the loss of US market quotas attached to the MFA.

In the argument I have presented above, I note that the Fiji Sugar Cane Growers' Council's leader, Jaganath Sami, projected that 'by 2009, at least 65 per cent of cane farmers may not be viable'. ${ }^{55}$ This is a worst-case scenario. However, it is already clear that a significant number of cane growers whose families will no longer be in a position to live from the proceeds of their crops will move to town and it is equally clear that the quality of their lives will be impacted greatly by the policies adopted by their government. Not only will they require their share of the funds flowing into Fiji to offset the negative impact of the end of trade and price preferences for sugar, they will need to benefit from innovative polices adopted by their government with respect to the provision of housing and secure tenure of suitable land; the provision of basic services such as water, electricity and sewerage; promotion of the informal economy, including the possible licensing of informal trading enterprises such as roadside stalls and backyard mechanical repair shops; the provision of accessible grassroots saving opportunities and micro-credit facilities; and suitable investment in human capital, particularly in the training of workers. 
The growth in remittances is a bright spot on Fiji's economic landscape. Remittances are being touted by international bodies such as the World Bank, the IMF, the ADB, the ILO and even APEC as a means of providing 'the most direct, immediate, and far-reaching benefit for overseas workers, their families, and their countries of origin'. The authors of such glowing endorsements then often go on to note that 'despite the social and other costs of migration, many families of overseas workers, particularly those in the low-income sectors, rely on remittances'. It is this reliance that has led to the current push to identify measures that would 'harness' inflowing funds as an investment resource. There would be considerable benefit to be derived from schemes intending to channel these funds into projects such as the establishment of grassroots credit cooperatives or micro-banks. However, there is another face to the current push to 'harness' remittance monies. It relates to what has been described enthusiastically as the 'generation of vibrant competition among banks, money transfer agencies, and other traditional remittance players ... to serve as remittance conduits'. These banks, money transfer agencies and others are claiming for themselves the brief of facilitating the shift of remittance payments from informal to formal channels. They claim that their participation in 'the remittance market' will benefit those who work overseas and remit monies to their families in their home country. ${ }^{56}$ However, there is room for some suspicion when it comes to assessing their claim to be promoting primarily altruistic motives. Western Union's 'vision' of ever-more McDonald's restaurant outlets for money transfers serves to underline the predominantly commercial, profit-driven nature of their endeavours.

\section{References}

Appana, Subhash. 2003. 'New Public Management and Public Enterprise Restructuring in Fiji.' Fijian Studies: A Journal of Contemporary Fiji, 1, 1. pp. 51-73.

Asian Development Bank. 2005. Pacific Economic Outlook 2005. (See particularly 'Fiji Islands', pp. 192-5.) Manila.

Asian Development Bank. 2005. Enhancing the Efficiency of Overseas Workers' Remittances. Technical Assistance Report. Manila.

AusAID. 2005. Summary of Australia's Overseas Aid Program 2005/6. Canberra.

AusAID. 2006. Australian Aid: Promoting Growth and Stability, A White Paper on the Australian Government's Aid Program. Canberra.

Australian Broadcasting Commission, Radio Australia, Pacific Beat, September 30, 2005, http://www.abc.net.au/ra/pacbeat/

Barr, Kevin. 2003. 'Wages Councils and Just Wages in Fiji.' Fijian Studies: A Journal of Contemporary Fiji, 1, 1. pp. 199-208. 
Bezard, Gwenn (Celent Communications speaker). 2004. 'Global Money Transfers - Can New Technologies Bring More Competition?' Shaping the Remittances Market by Shifting to Formal Systems, APEC Symposium, Tokyo, June 3-4.

Chami, R., C. Fullenkamp and S. Jahjah, 2003 'Are Immigrant Remittance Flows a Source of Capital for Development?', IMF Working Paper 03/189, IMF, September

Commission of the European Communities. 2005. 'The Trade and Development Aspects of EPA Negotiations.' Commission Staff Working Document, November 9.

Commonwealth of Australia. 2006. Pacific 2020: Challenges and Opportunities for Growth. May.

Connell, John and Richard Brown. 2005. Remittances in the Pacific: An Overview. Asian Development Bank. March.

Cruz, Isabel. 2004. 'Rural Microbanks - Financial Services for Local Development.' Shaping the Remittances Market by Shifting to Formal Systems, APEC Symposium, Tokyo, June 3-4.

Department of Foreign Affairs and Trade. 2003. Scoping Study: Future Directions for Fiji's Garment Industry. Economic Analytical Unit. August.

Economic Association of Fiji. 2005. Published Panel Discussion: 'Sugar Reforms: Do We Have a Choice?' Reserve Bank of Fiji Quarterly Review, March. pp. 34-6.

European Commission. 'Bilateral Trade Relations: Africa, Caribbean, Pacific.' http://ec.europa.eu/comm/trade/issues/bilateral/regions/acp/index_en.htm

European Commission. 'EU-ACP Microfinance Framework Programme.' http://ec.europa.eu/comm/europeaid/projects/microfinance/index_en.htm

European Commission. 2004. Pacific ACP-EC EPA Negotiations Joint Road Map. EC: Directorate-General for Trade.September 15.

European Commission. 'The Cotonou Partnership Agreement.' http://europa.eu.int/comm/development/cotonou

Fiji Sugar Corporation. 2003. 'A Brief History of the Sugar Industry in Fiji.' Briefing notes prepared for the EU Commissioner for Development and Humanitarian Affairs, 2002, reproduced in Fijian Studies: A Journal of Contemporary Fiji, 1, 2. pp. 315-26.

Fiji Times, 'Sugar Prices to Fall by July 2006', January 7, 2005; 'More Dollars From Abroad', January 24, 2005; 'Stay Out of Politics, Army Told', September 30, 2005. 
Gillson, Ian, Adrian Hewitt and Sheila Page. 2005. Forthcoming Changes in the EU Banana/Sugar Markets: A Menu of Options for an Effective EU Transitional Package. London: Overseas Development Institute.

Handelman, Howard. 2003. The Challenge of Third World Development, 3rd ed. New Jersey and London: Prentice Hall.

Hannan, Kate. 2005. 'China's Rural-to-Urban Labour Migration: Mobility, Exclusion and Opportunity.' International Convention of Asia Scholars (ICAS) 4 Conference, Shanghai, August 20-24.

Hannan, Kate. 2006. 'China's Trade Relations with the US and the EU: WTO Membership, Free Markets(?), Agricultural Subsidies and Clothing, Textile and Footwear Quotas.' Copenhagen Business School Discussion Paper, May.

Holland, Martin. 2002. The European Union and the Third World. Palgrave.

House of Commons International Development Committee. 2005. 'Fair Trade? The European Union's Trade Agreements with African, Caribbean and Pacific Countries.' Sixth Report of Session 2004-05. March 23, 2005.

Kingsbury, Damien, Joe Remenyi, John McKay and Janet Hunt. 2004. Key Issues in Development. New York: Palgrave Macmillan.

Murphy, Craig N. (ed.) 2003. Egalitarian Politics in the Age of Globalization. New York: Palgrave Macmillan.

Narayan, Paresh and Biman Prasad. 2003. 'Fiji's Sugar, Tourism and Garment Industries: A Survey of Performance, Problems and Potentials.' Fijian Studies: A Journal of Contemporary Fiji, 1, 1. pp. 3-27.

National Farmers Union. 2003. 'Dark Clouds on the Horizon.' Fijian Studies: A Journal of Contemporary Fiji, 1, 2. pp. 381-8.

Nielson, Poul (European Commission Commissioner for Development and Humanitarian Aid). 2002. Speech to the ACP-EU First Meeting on Negotiation of Economic Partnership Agreement, Brussels, September 27, 2002. (See also European Union Press Release, October 4, 2002, 'Commission Signs EUR 29 Million Aid Package with the Pacific Island Countries', http:/europa.eu.int/rapit/start/ggi/guesten.ksh? p_action.getxt $=$ gr\&doc $=$ IP $/ 02 / 1432 /$ RA)

New Zealand Ministry of Foreign Affairs and Trade, Pacific Division, 2002. Economic Update - Republic of the Fiji Islands. October.

O'Brien, Robert and Marc Williams. 2004. Global Political Economy: Evolution and Dynamics. New York: Palgrave Macmillan.

Pacific Islands Forum. 2005. 'Urbanisation and the Pacific.' Trends and Developments, January. 
Pacific Islands Report, 'ADB Outlook for Fiji Economy Grim', April 7, 2005; 'Fiji's Long, Risky Road to Kuwait', April 22, 2005; '3,000 Lose Jobs As Fiji Garment Factory Closes', April 26, 2005; and 'Fiji Gets \$25 Million ADB Loan for Farmers', June 30, 2005.

Pareti, Samisoni. 2005. 'Human Labour - Lucrative Export — Fiji Rakes in \$m From Overseas Jobs.' Islands Business, May.

Prasad, Satendra and Kevin Hince. 2001. Industrial Relations in the South Pacific. Suva: USP.

Prasad, Satendra. 2003. 'Energy Aspects of Fiji's Sugar Industry: A Case for More Efficient Electricity Generation from Bargasse.' Fijian Studies: A Journal of Contemporary Fiji, 1, 2. pp. 243-64.

Rao, Gyaneshwar, 2003. 'Lending Trends in the Sugar Cane Sector in Fiji.' Fijian Studies: A Journal of Contemporary Fiji, 1, 2. pp. 301-15.

Reddy, Mahendra. 2003. 'Farm Productivity, Efficiency and Profitability in Fiji's Sugar Industry.' Fijian Studies: A Journal of Contemporary Fiji, 1, 2. pp. 225-41.

Reddy, Mahendra, Vijay Naidu and Manoranjan Mohanty. 2003. 'The Urban Informal Sector in Fiji: Results From a Survey.' Fijian Studies: A Journal of Contemporary Fiji, 1, 1. pp. 127-54.

Reddy, Narendra. 2003. 'Survival Strategies for the Fiji Sugar Industry.' Fijian Studies: A Journal of Contemporary Fiji, 1, 1. pp. 265-85.

SBS-TV, Dateline, 'The Real Pacific Solution', June 15, 2005, transcript, Dateline Archives, http://news.sbs.com.au//dateline/index:php?

Secretariat of the African, Caribbean and Pacific Group of States, Press Release/Brussels: 'African, Caribbean and Pacific (ACP) countries express extreme dissatisfaction with EU sugar reform proposals and accompanying measures - Reform too fast, too deep, and too soon', June 22, 2005.

Schuurman, Frans (ed.) 2001. Globalization and Development Studies: Challenges for the 21 st century. Sage.

Storey, Donovan. 2003. 'The Fiji Garment Industry.' OXFAM.

Sugar Commission of Fiji. 2003. 'Sugar Industry Strategic Plan.' Fijian Studies: A Journal of Contemporary Fiji, 1, 2. pp. 327-88.

Sydney Morning Herald, 'ALP Floats Single Pacific Market', September 30, 2005; The Australian, 'Howard Backs Jobs Over Trees', October 7, 2004, and 'PM's \$4m Poll Deal With Union', October 7, 2005

Weekend Australian, 'Islander Jobs Push Attacked', October 1-2, 2005. 


\section{White, Michael. 2003. 'The Financial Viability of Fiji Sugar Corporation: An Assessment from the Corporation's Annual Financial Reports.' Fijian Studies: A Journal of Contemporary Fiji, 1, 2. pp. 286-300.}

\section{ENDNOTES}

1 A very useful account of the problems facing Fiji's sugar and garment (and tourist) industries is Narayan and Prasad, 2003, pp. 3-27. The end of the Multi-Fibre Arrangement has also ended the stable distribution of garment quotas to developing countries for imports to the EU and Canada.

2 There is considerable evidence of government dithering and disagreement over reform of the sugar industry and there have long been 'allegations of corruption and mismanagement in the FSC [Fiji Sugar Corporation]'. See Narayan and Prasad, 2003, p. 19.

3 Commentators and academics often agree that the percentage of people living from the informal economy who are resident in Suva is at least 60 per cent and many would argue that it is likely to be higher. Conversation with Professor Biman Prasad, USP.

4 Those who represent the interests of international financial capital are now talking of a pressing need to 'shape the remittances market by shifting to formal systems'. It seems that while those whose interests are associated with global investment have been very successful in resisting the calls to regulate capital flow using measures such as the Tobin Tax, there is a considerable push to ensure that the flow of workers' funds in the form of remittances is subject to regulation and control. (Calls to regulate investor capital flows were particularly loud in the wake of the 1997 Asian financial crisis.) The Tobin Tax has been usefully profiled as a tax that 'would levy a charge on foreign exchange dealings. The idea is that the tax would discourage those people trading currencies just to make money, but would not deter foreign exchange transactions for purposes such as medium to long term investment, buying imports or tourism.' It has been noted that 'although there are technical objections to the Tobin Tax and other measures to slow [and regulate] the flow of capital, the primary obstacles are political'. See O'Brien and Williams, 2004, pp. 246 and 248-50. Apart from interests obviously associated with international capital (with companies such as Western Union and banks who favour ATM-facilitated remittances, there are also calls from such esteemed bodies as the World Bank, the ADB and even APEC to effect remittance controls. If these controls are implemented successfully (and this is by no means a foregone conclusion) the effects and the effectiveness of this form of financial regulation are unknown.

5 See 'Fiji Gets \$25 Million ADB Loan for Farmers', Pacific Islands Report, June 30, 2005; 'Summary of Australia's Overseas Aid Program 2005/6', AusAID, 2005; and 'Summary of Australia's Overseas Aid Program 2006-7', AusAID, 2006. See also Poul Nielson's (EC Commissioner for Development and Humanitarian Aid) speech to the ACP-EU First Meeting on Negotiation of Economic Partnership Agreement held in Brussels on September 27, 2002 and the EU press release dated October 4, 2002 titled 'Commission signs EURO 9 million aid package with the Pacific Island countries'. This speech is available on: http://europa.eu.int/rapit/start/ggi/guesten.ksh?p_action.gettxt=gt\&doc=IP/02/1432/RA

6 House of Commons International Development Committee, Sixth Report of Session 2004-05, titled 'Fair trade? The European Union's trade agreements with African, Caribbean and Pacific Countries', published March 23, 2005; the EC, 'The Cotonou Partnership Agreement', http://europa.eu.int/comm/development/cotonou/statistics/stat01

7 Ibid., and Gillson et al., 2005, particularly p. 10. There has been (and still is) considerable confusion over the starting date for the reduction of benefits derived by ACP countries from the EC's Sugar Protocol. There are now 79 ACP countries. See Holland, 2002, particularly p. 113.

8 Gillson et al., 2005, p. 4.

9 Ibid., p. 9. Commentators who note that the protocol 'cannot be changed unilaterally' have also noted that 'it may be denounced by the EU, with respect to each ACP state and by each ACP state with respect to the EU, subject to two years' notice', ibid., p. 30. See also Pacific ACP - EC EPA Negotiations Joint Road Map, EC Directorate-General for Trade, Brussels, September 15, 2004.

10 Gillson et al., 2005, p. 31.

11 Ibid., p. 9.

12 Alexander Downer's comment is as quoted in an editorial titled 'Stay Out of Politics, Army Told', Fiji Times, September 30, 2005.

13 See Narayan and Prasad, 2003, p. 17; Reddy, Narendra, 2003, pp. 225-31; and Rao, 2003, pp. 301-14, particularly p. 304. See also White, 2003, pp. 287-300. 
14 Gillson et al., 2005, pp. 34-5.

15 Narayan and Prasad, 2003, pp. 17-21; Narendra, Reddy, 2003, p. 266; and Fiji Sugar Corporation, 2003 pp. 315-26 (see particularly p. 316). It is worth pointing out that because sugar entering the EU under the preferential quota system is priced 'at levels similar to those paid to EU producers ... there is no price competition [within the EU] between preferential sugar imports and domestic [sugar beet] production. It is also worth noting that in 2003-04 the subsidy for exported excess EU white sugar was 511 per metric tonne. The extent of the above global market price paid by the EU is underlined when it is noted that when the EU re-exports sugar that is surplus to its own market it must supplement the average export cost in order to meet the price expectations of the international marketplace. See Gillson et al., 2005, pp. 3land 35-6. The March 2005 figures have been drawn from Economics Association of Fiji Panel Discussion, 2005.

16 Isikeli Mataitoga's comment at the Economics Association of Fiji Panel Discussion, op. cit., pp. 35-6. See also 'Sugar Prices to Fall by July 2006', Fiji Times, July 1, 2005.

17 Fiji's garment industry was nurtured in the wake of the 1987 coups. It was in 1987 that the Tax Free Factory scheme was introduced. This scheme allowed factories exporting more than 70 per cent of production to enjoy a tax holiday for 13 years. For most of the period of the scheme the tax holiday meant there was no customs duty on imported capital goods, no withholding tax on interest, dividends or payments abroad and when the final dividends to resident Fijian shareholders were taxed it was at 15 rather than 35 per cent. See Storey, 2003, p. 9.

18 In China garment production is undertaken by rural-to-urban migrants who have been provided with little or anything in the way of services, housing, education and decent health and safety-based working conditions. Their pay is often withheld by their employers, usually for up to one year, and there are many reports of unpaid overtime being extracted from workers by using threats such as 'illegal' deductions from wages for refusing to work hours that are reported as often lasting from 7am to midnight. See Hannan, 2005 and 2006.

19 See Storey, 2003, p. 26. It has been estimated that as much as 90 per cent of overtime done by Fijian garment workers was paid at 'the proper rate'. See DFAT, 2003, p. 32.

20 See DFAT, 2003, pp. 8-9.

${ }^{21}$ While SPARTECA (signed at the 11th Pacific Islands Forum in July 1980) 'allowed garment manufacturers in Fiji preferential but non-reciprocal access to markets in Australia and New Zealand', throughout the 1990s (from 1991) it was an Import Credit Scheme (ICS) that provided particular benefit. See Storey, 2003, pp. 10-11. However, a number of commentators have voiced some criticism of this scheme. For example, Storey has pointed out that 'the ICS relationship proved very good for Australian fabric makers'. He has also approvingly cited an argument that notes that an agreement (i.e., SPARTECA) that nurtures 'a strong relationship between Fiji exports of garments to Australia and New Zealand and her imports of textile yarn from the same destinations ... implies that SPARTECA ... may not be, as claimed, a non-reciprocal trade arrangement'. See Storey, 2003, pp. 13-14. Nevertheless, there is no doubt that the ICS scheme provided considerable incentives to Australian companies who 'received import credits in return for exports of eligible TCF products; these credits could be [were] used to reduce the customs duty payable on eligible TCF imports ... Exports to Pacific Island Forum countries were eligible for credits despite the existence of SPARTECA'. See DFAT, 2003, p. 12. For its part, the TaxFree Factory scheme, had given 'tax and duty concessions to companies exporting more than 95 per cent of their output. They are exempted from company tax for 13 years [beginning 1987] and import and licensing duties on capital goods and production materials.' The scheme also allowed for final dividends paid to Fijian resident shareholders to be taxed at 15 rather than the usual 35 per cent. As noted above, 'bilateral trade in TCF products between Australia and Fiji boomed in the 1990s but has fallen significantly as preferences have wound down'. See DFAT, 2003, pp. 3 and 11, and Storey, 2003, p. 9. For comment/explanation concerning the S-TCF scheme, see footnote 23 below.

22 Storey, 2003, p. 11.

23 The Australian Government began the S-TCF scheme in March 2001 with the express purpose of reducing the impact of the end of the ICS. 'The S-TCF scheme allows certain TCF goods manufactured in FICs [Forum Island Countries] but not meeting all the provisions of SPARTECA to enter Australia duty free in certain circumstances. In particular, excess local area content, or local content above 70 per cent, can be distributed to other imports with local area content below the required level, that is between 35 and 49 per cent.' As I have noted in the text above, this scheme has now been extended to the year 2011. See DFAT, 2003, p. 13. However, there seems to be a general agreement that this scheme 'has been ineffective, with many industry representatives, both in Fiji and Australia claiming it is overly 
complicated and offers little incentive for Australia-Fiji TCF trade'. See Storey, 2003, p. 18. See also Radio Australia, Pacific Beat, September 30, 2005, http://www.abc.net.au/ra/pacbeat/stories/s

24 See 'The Real Pacific Solution', Dateline Archives, June 15, 2005, http://news.sbs.com.au/dateline/index.php?

25 DFAT, 2003, p. 1.

26 Storey, 2003, p. 53. An estimate made in 2002 listed 18,000 people (80 per cent of them women) employed in Fiji's garment industry. However, when it is remembered that a further 3,000 workers lost their jobs when Ghim Li Garments in Lautoka was closed in April 2005, the current figure of 15,000 workers is likely to be too high. See DFAT, 2003, p. 3, and ' 3000 Lose Jobs as Fiji Garment Factory Closes', Pacific Islands Report, April 26, 2005.

27 Quoted from Australian Bureau of Agricultural Resource Economics Report, 2002 cited in DFAT, 2003, p. 2.

28 Narendra, Reddy, 2003, p. 269. See also DFAT, 2003, p. 16; and Economics Association of Fiji Panel Discussion, op. cit., p. 34. The most alarming reports estimate that 'the impact zone of the [sugar] industry collapsing would mean that approximately 250,000 people, who directly or indirectly depend on the sugar industry for their livelihood, would have nothing to sustain them'. Regardless of the figures they use, most commentators expect that rural and urban poverty will increase in the near future.

29 ADB Pacific Economic Outlook 2005, p. 195, and Storey, 2003, p. 33.

30 ADB Pacific Economic Outlook 2005. See section titled 'Fiji Islands', pp. 192-5, particularly p. 192.

31 See Barr, 2003, pp. 199-200.

32 In Australia, the administrators of the cities of Geelong, Newcastle and Wollongong have all been keen to emphasise the role of their resident universities when constructing their city's new image.

33 Suva's population (or the population of other Fijian cities such as Lautoka or Ba) cannot be seen to have increased substantially due to employment offered in the garment industry; rather the garment industry has provided employment for existing residents and so the loss of jobs in this industry does not result in an outward population flow. It is more likely that workers will be driven from the formal to the informal sectors of the economy.

34 Ton van Naerssen, 'Cities and the Globalization of Urban Development Policy', in Schuurman, 2001, pp. 177-95.

35 It has been pointed out that if the issues surrounding the pressing need to restructure Fiji's sugar industry are not carefully addressed, the sugar towns of Labasa, Rakiraki, Tavua and Ba could become 'ghost towns'. Narayan and Prasad, 2003, p. 17.

36 See 'Rapid Urbanization and the Politics of the Urban Poor', Handelman, 2003, pp. 174-98, and Pacific Islands Forum, 2005, pp. 14-17. Also see Biman Prasad, 'Economics Association of Fiji Panel Discussion', op. cit., p. 34, and Commonwealth of Australia, 2006, particularly pp. 5, 89 and 93.

37 The same could be said for China's cities today where, in the wake of the end of the Multi-Fibre Arrangement, many of China's eastern seaboard cities are reporting a significant shortage of entry-level unskilled migrant workers.

38 Kingsbury et al., 2004, p. 130.

39 See Reddy, Naidu and Mohanty, 2003, p. 129. This group of particularly well-informed authors has noted that 'the debate over what comprises the formal and what [is] the informal sector, is still far from resolved'. Nevertheless, they have sensibly defined Fiji's urban informal employment sector as 'that part of the economy which is not part of the formal sector'. They go on to note that 'as such there is no official record of informal enterprises. Nor do such enterprises pay taxes'. They then give examples of informal enterprises: 'the road-side vendors, bottle sellers, back-yard mechanics and other crafts-men, domestic workers, hawkers and shoe shine boys. Included also are illegal activities like prostitution and drug peddling'. See also p. 131 and p. 146 and see 'EU-ACP Microfinance Framework Programme', http://ec.europa.eu/comm/europeaid/projects/acp/microfinance/index_en.htm, accessed on May 13, 2006.

40 See Handelman, 2003, pp. 177-92. Also see Pacific Islands Forum, 2005. The authors of this paper cite 'numerous and serious' problems associated with urbanisation in Pacific Island countries and then attempt to put a brave face on matters by announcing that the concentration of large proportions of the population in urban areas is both a challenge and an opportunity for government ... the opportunities of scale, scope and concentration presented could be seized upon, which would mean transport, health, education, sanitation and other services being provided'. 
41 See ibid. It is in line with this view that the Australian Government has recently been stressing the need to offer funding to assist Pacific Island governments, including the Fiji Government, to provide improved means of land administration and for the development of urban infrastructure ('from roads to solid waste management'). See Commonwealth of Australia, 2006 and Australian Aid: Promoting Growth and Stability, A White Paper on the Australian Government's Overseas Aid Program, Australian Government/AusAID, 2006.

42 'More Dollars From Abroad', Fiji Times, January 24, 2005. It has also been estimated that remittances from Fijian citizens living abroad have quadrupled since 1994. Radio Australia, Country Profile, http://www.radioaustralia.net.au/news/countries/FIJI_to.htm, accessed on September 30, 2005.

43 See 'The Real Pacific Solution', op. cit., June 15, 2005; Australian Aid: Promoting Growth and Stability, and Commonwealth of Australia, 2006

44 Connell and Brown, 2005, particularly p. 46.

45 Ibid. and Cruz, 2004.

46 It is argued that all Fijians who work overseas must be protected by their government. Samisoni Pareti, ‘Human Labour — Lucrative Export - Fiji Rakes in \$m From Overseas Jobs', Islands Business, May 2005. In a recent (April 2006) conversation with Roman Grynberg from the Pacific Islands Forum it was noted that the forum had been successful in an agreement with the EC that would allow Pacific Island workers to stay in EU countries for agreed periods and under agreed conditions.

47 Ibid.

48 See 'Fiji's Long, Risky Road to Kuwait', Pacific Island Report, April 22, 2005, and 'The Real Pacific Solution', Dateline Transcript, June 16, 2005, http://news.sbs.com.au/dateline/index.php?page=transcript\&dte $=2005-06-15 \&$ headlineid $=$

49 Murphy, 2003, pp. 194-5.

50 Bezard, 2004. It is also worth noting that in the case of the Philippines, where overseas workers and worker remittances are well established, research has shown that 'nine out of 10 [respondents] said they save in banks or through personal hoarding, with 70\% maintaining bank accounts in the Philippines and 52\% using an automated teller machine (ATM) for their payments or remittances'. See ADB Technical Assistance Report, 'Enhancing the Efficiency of Overseas Workers' Remittances', 2005, p. xiv.

51 Chami, C. Fullenkamp and S. Jahjah, 2003, quoted in ADB Technical Assistance Report, op. cit., p. 9.

52 Peter Stalker, 'Proceedings on the NOVIB Experts Meeting on Migration, Globalization and Development', held in the Netherlands, March 2003, cited in ADB Technical Assistance Report, op. cit., p. 9.

53 Australian Aid: Promoting Growth and Stability, particularly p. 39

54 House of Commons, International Development Committee Report, op. cit., particularly p. 23.

55 Fiji Times, 'Sugar Prices to Fall by July 2006', January 7, 2005.

56 ADB Technical Assistance Report, op. cit., pp. 1-2. 